\title{
Pengembangan Media Visual Berbasis Kartun Pembelajaran Matematika untuk Kelas II Sekolah Dasar
}

\author{
Lestari $^{1}$ \\ ${ }^{1}$ SDN 122/IX Petaling, Jambi, Indonesia
}

\begin{tabular}{l}
\hline Article Info \\
\hline Article history: \\
Received Mei 7, 2020 \\
Revised Mei 15, 2020 \\
Accepted Mei 28, 2020 \\
\hline
\end{tabular}

\begin{abstract}
ABSTRAK
Tujuan Penelitian: Penelitian ini adalah penelitian pengembangan media visual berbasis kartun pembelajaran matematika di kelas II Sekolah Dasar 122/IX Petaling. Penelitian ini bertujuan untuk mengetahui bagaimana prosedur pengembangan kartun pembelajaran matematika, dan bagaimana kelayakan kartun pembelajaran matematika dilihat dari kevalidan, kemenarikan dan keefektifan kartun pembelajaran matematika.
\end{abstract}

\section{Keywords:}

Media Kartun

Media Visual

Pembelajaran Matematika

\begin{abstract}
Metodologi: Penelitian pengembangan ini menggunakan Model pengembangan Dick and Carey. Prosedur pengembangan melalui sepuluh tahap yaitu analisis kebutuhan, analisis pembelajaran, analisis peserta didik, merumuskan tujuan pembelajaran, mengembangkan instrumen penilaian, mengembangkan strategi instruksional, mengembangkan dan memilih bahan media, merancang dan melakukan evaluasi formatif, melakukan revisi, evaluasi sumatif.
\end{abstract}

Temuan Utama: Hasil penelitian ini berupa prosedur pengembangan yang menghasilkan kartun pembelajaran matematika yang layak dilihat dari kevalidan, kemenarikan dan keefektifan. Hasil validasi dilakukan oleh para ahli diperoleh hasil dari $88,1 \%$ dari ahli desain media dan $94 \%$ dari ahli pembelajaran, dengan kategori layak tanpa perlu direvisi. Setelah itu dilakukan uji coba kelompok kecil, dengan hasil bahwa kartun pembelajaran matematika menarik. Hasil uji coba lapangan, ada kenaikan ketuntasan keseluruhan dari hasil belajar dari sebelum menggunakan media kartun pembelajaran matematika yaitu $6,54 \%$ menjadi $85,4 \%$ sesudah menggunakan kartun pembelajaran matematika. Dengan demikian terbukti bahwa hasil pengembangan media visual berbasis kartun pembelajaran matematika ini efektif.

Aplikasi dalam Penelitian: Pengembangan media pembelajaran sangat penting dilakukan agar guru memiliki banyak opsi didalam pembelajaran.

Keterbarauan: Sebuah media pembelajaran yang baru berbasis visual untuk pembelajaran matematika anak kelas 2 sekolah dasar.

Copyright @ 2020 Cahaya Ilmu Cendekia Publisher. All rights reserved.

\section{Corresponding Author:}

Lestari

SDN 122/IX Petaling

Email: Lestari122@gmail.com

\section{PENDAHULUAN}

Matematika adalah salah satu muatan pembelajaran wajib yang diberikan mulai dari SD/MI sampai SMA/MA sederajat. Matematika adalah ilmu deduktif, aksiomatik, formal, hierarkis, abstrak, bahasa simbol yang padat anti dan semacamnya [1]. Karakteristik pembelajaran matematika yang merupakan ilmu deduktif, formal dan abstrak bertentangan dengan karakteristik peserta didik kelas II Sekolah Dasar yang memiliki cara berpikir induktif karena berdasarkan usianya masih berada pada tahapan operasional/operasi konkret. Diperlukan kemampuan khusus dari seorang guru untuk menjembatani antara dunia anak yang belum 
berpikir secara deduktif agar dapat mengerti dunia yang bersifat deduktif [2]. Ada pun salah satu cara yang dapat dilakukan guru untuk menjembatani antara dunia anak agar dapat mengerti dunia matematika yang bersifat deduktif yaitu dengan memvisualkan pembelajaran matematika. Memvisualkan pembelajaran matematika dapat dilakukan dengan menggunakan media visual. Kelebihan dari media ini yaitu dapat memperlancar pemahaman dan memperkuat struktur ingatan [3]. Media visual dapat pula menumbuhkan minat peserta didik.

Media visual yang dapat digunakan dalam pembelajaran matematika salah satunya adalah kartun. Media kartun adalah media yang dapat mengkomunikasikan pembelajaran matematika melalui gambar dan kata-kata secara sederhana dan menarik [4]. Hal tersebut sesuai dengan minat peserta didik Kelas II Sekolah Dasar yang menyenangi gambar yang menarik dan bahasa yang sederhana namun mudah dimengerti. Kartun dapat digunakan menghilangkan pesan yang bersifat verbalisme dengan memberikan penjelasan secara lengkap dan sesuai dengan karakteristik peserta didik kelas II Sekolah Dasar. Melalui bentuk kartun yang sederhana, penyampaian materi pembelajaran matematika dapat lebih mudah dipahami oleh peserta didik. Selain itu, gambar pada kartun dapat menarik minat peserta didik untuk mengerjakan soal yang terdapat di dalamnya. Kartun sangat mudah dan cepat di baca dan di minati anak-anak dan juga orang dewasa [6].

Sebagaimana yang telah dikemukan di atas maka perlu ada sebuah kartun yang dapat digunakan sebagai media pembelajaran matematika untuk peserta didik kelas II Sekolah Dasar. [6] Namun kartun murni cenderung berfungsi sebagai hiburan. Media kartun yang telah ada dikembangkan sebagai media pembelajaran oleh peneliti lain satu gambar kartun hanya dapat menjelaskan satu permasalahan matematika, tidak dapat diubah secara langsung, padahal berdasarkan observasi yang dilakukan pada 28 juli 2017 diketahui bahwa peserta didik membutuhkan banyak contoh agar dapat memahami pembelajaran matematika. Bahan yang digunakan untuk mencetak kartun umumnya adalah kertas yang tidak tahan lama. Ada pun kartun yang dapat diubah adalah kartun yang dikembangkan sebagai multimedia[7]. [8]Tetapi kartun multimedia membutuhkan alat tambahan yang menggunakan listrik yang tidak cocok diterapkan pada sekolah dengan sarana prasarana terbatas. Berdasarkan keterbatasan media tersebut, maka media kartun perlu dikembangkan lagi.

\section{METODE PENELITIAN}

Penelitian ini merupakan penelitian dan pengembangan (R \& D) dengan model Dick \& Carey yang telah terdiri dari sepuluh langkah yaitu analisis kebutuhan, analisis pembelajaran, analisis peserta didik, merumuskan tujuan pembelajaran, mengembangkan instrumen penilaian, mengembangkan strategi instruksional, mengembangkan dan memilih bahan media, merancang dan melakukan evaluasi formatif, melakukan revisi, evaluasi sumatif. Subjek uji coba pada penelitian ini yaitu coba 6 orang peserta didik kelas II SDN 122/IX Petaling, dan 1 orang guru kelas pada uji coba kelompok kecil. 31 orang peserta didik kelas II SDN 122/IX Petaling pada uji coba lapangan.

Jenis data pada penelitian ini adalah jenis data deskriptif kualitatif dan deskriptif kuantitatif. Instrumen yang digunakan pada penelitian ini yaitu lembar angket, lembar wawancara dan tes [9].

\section{HASIL DAN PEMBAHASAN}

Setelah melakukan pengembangan media visual berbasis kartun pembelajaran matematika diperoleh hasil sebagai berikut: Satu berupa kartun yang dibuat berbentuk lembar-lembaran disimpan di dalam kotak yang juga berfungsi sebagai sampul luar. Terdapat 11 kartun yang terdiri 10 kartun untuk pembagi 1 - 10 dan 1 kartun untuk sampul yang digunakan pada kotak. Setiap gambar kartun menceritakan tentang cerita operasi pembagian bilangan cacah sampai dengan 99.

Hasil validasi oleh ahli media dan ahli pembelajaran secara keseluruhan produk kartun pembelajaran matematika dalam kategori "Sangat Baik". Secara persentase hasil dari ahli media 88,1 \% dan ahli pembelajaran $96 \%$. Hasil penilaian kemenarikan dari wawancara dengan 6 peserta didik dan 1 guru kelas II SDN 122/IX Petaling yaitu menurut para peserta didik warna dan bentuk kartun pembelajaran matematika bagus. Dari segi bahasa yang digunakan dalam media kartun pembelajaran matematika mudah dipahami. Saat belajar menggunakan media kartun pembelajaran matematika 5 orang peserta didik menjawab "senang" dan 1 orang peserta didik menjawab "senang sekali". Ada pun kekurangan yang didapat dalam proses pembelajaran dengan menggunakan media kartun pembelajaran matematika sebanyak 4 orang menjawab "tidak ada" dan 2 orang menjawab "tidak".

Hasil evaluasi sumatif uji coba lapangan dilihat pada aspek keterampilan diperoleh nilai rata-rata 3 dengan kategori baik. Ada pun kriteria untuk kategori baik adalah peserta didik yang menghitung hasil bagi dua bilangan yang melibatkan bilangan cacah sampai dengan 100 dengan bantuan guru pada awal kegiatan. Hasil evaluasi formatif pada aspek pengetahuan menggunakan instrumen penelitan berupa pre test dan post 
test. Peserta didik dinyatakan tuntas apabila telah mencapai KKM yaitu skor 65. Ketuntatasan keseluruhan peserta didik dapat dihitung dengan rumus modifikasi dari [10] diperoleh ketuntasan keseluruhan pada pre test sebesar $6,45 \%$ dan pada post test $80,64 \%$.

Pembahasan dalam penelitian ini dilakukan berdasarkan hasil identifikasi masalah dengan cara wawancara dan observasi. Berdasarkan hasil identifikasi masalah, wawancara dan observasi yang dilakukan di kelas II SDN 76/X Muara Sabak sebagai tempat sampel penelitian menunjukkan bahwa ketersediaan media pembelajaran masih terbatas. [11] Melalui angket yang ditujukan oleh ahli bidang, seperti ahli media, ahli pembelajaran dan ahli bahasa menjadi data untuk memperkuat proses penelitian, ahli media mengatakan bahwa kartun pembelajaran matematika layak digunakan sesuai dengan karakteristik anak usia 7-11 tahun (tahap operasi konkret).

Data lain seperti wawancara pada peserta didik yang mengatakan bahwa peserta didik kelas II senang dan mudah belajar menggunakan media tangga satuan karena peserta didik dapat lebih mudah belajar matematika dengan adanya kartun pembelajaran matematika. Beberapa data yang diperoleh tersebut menjadi pertimbangan dan bahan penelitian untuk melakukan penelitian di kelas II dan mengembangkan kartun pembelajaran matematika.

Data yang dianalisis dalam penelitian ini adalah hasil data yang diperoleh dari pengisian angket oleh validator pada saat validasi dan tanggapan hasil dari wawancara guru dan wawancara peserta didik pada saat uji kelompok kecil. Data yang diperoleh dalam penelitian ini, yaitu data kualitatif. Data dalam penelitian ini adalah hasil data dalam bentuk lembar angket dan lembar wawancara. Pada penelitian ini, instrumen yang digunakan berupa angket validasi dan instrumen wawancara. Data angket dianalisis dengan analisis deskriptif kualitatif. Analisis deskriptif kualitatif, pernyataan-pernyataan yang diajukan, baik pernyataan positif maupun pernyataan negatif dinilai dari responden. Penelitian ini menggunakan pernyataan positif dengan skor yang diberikan, yaitu 1 = berarti sangat kurang, 2 = berarti kurang, 3 = berarti cukup, 4 = berarti baik, 5 = berarti sangat baik. Skor yang diperoleh kemudian dipersentasekan untuk melihat tingkat kevalidan kartun pembelajaran matematika. Proses pengembangan kartun di kelas II sekolah dasar dilakukan dengan menggunakan model pengembangan Dick \& Carey.

Model Dick \& Carey merupakan salah satu model desain pembelajaran yang sistematis yang dapat digunakan dalam pengembangan suatu produk. Model ini disusun secara sistematis dalam upaya pemecahan masalah belajar yang berkaitan dengan media pembelajaran. Setiap tahapan dalam model Dick \& Carey rinci namun mudah dipahami dan diimplementasikan dalam mengembangkan produk pengembangan media pembelajaran. Berdasarkan validasi yang dilakukan diketahui bahwa kartun pembelajaran matematika pada proses pembelajaran termasuk dalam katagori valid baik dari ahli media dan ahli pembelajaran. Hal ini menunjukan bahwa kartun pembelajaran matematika yang dihasilkan dapat digunakan dalam pembelajaran. [12] validitas mempunyai arti sejauh mana ketetapan dan kecermatan suatu alat hitung dalam melakukan fungsinya. Produk yang telah dinyatakan valid kemudian dilakukan uji coba dengan melihat sejauh mana keterpakaianya. Pada tahap ini pengembang melakukan wawancara untuk mengetahui tanggapan guru dan peserta didik dan diperoleh praktikalitas dengan hasil yang baik. [13] pertimbangan praktikalitas dapat dilihat dalam aspek kemudahan penggunaan, dapat digunakan sewaktu-waktu, waktu singkat, cepat, sebagai penganti atau variasi serta biaya murah jika hendak menggunakannya".

Pengembangan ini menghasilkan kartun pembelajaran matematika yang layak dilihat dari kevalidan, kemenarikan dan keefektifan. Hal ini menunjukkan bahwa kartun pembelajaran matematika layak digunakan dalam proses pembelajaran. Selanjutnya dilihat dari respon guru dan peserta didik diperoleh hasil tanggapan yang baik dari guru dan peserta didik. Hal ini menunjukan bahwa media kartun pembelajaran matematika yang dihasilkan mempunyai daya tarik bagi peserta didik. Daya tarik biasanya ditandai dengan kecenderungan siswa untuk terus dan tetap belajar [14]. Keefektifan dilihat dari hasil belajar peserta didik melalui posttest dan pretest. Peningkatan hasil belajar peserta didik pada kompetensi 3.4 dan 4.4 khusus kemampuan pengetahuan dan keterampilan setelah menggunakan kartun pembelajaran matematika ini membuktikan bahwa kartun pembelajaran matematika ini efektif.

\section{KESIMPULAN}

Penelitian pengembangan ini menghasilkan produk yang berupa Kartun Pembelajaran Matematika. Produk ini dihasilkan melalui sepuluh langkah utama yaitu (1) analisis kebutuhan, (2) analisis pembelajaran, (3) analisis peserta didik (4) merumuskan tujuan pembelajaran, (5) mengembangkan instrumen penilaian, (6) mengembangkan strategi pembelajaran (7) mengembangkan dan memilih bahan media, (8) merancang dan melakukan evaluasi formatif, (9) melakukan revisi, dan (10) melakukan evaluasi sumatif. Kartun pembelajaran matematika ini layak dilhat dari kevalidan, kemenarikan dan keefektifan. Hal tersebut didapat dari hasil validasi oleh para ahli yang meliputi ahli desain media dan ahli pembelajaran diperoleh hasil $88,1 \%$ dari ahli desain media dan $94 \%$ dari ahli pembelajaran. Uji kemenarikan melalui wawancara peserta didik 
dan guru secara keseluruhan menyatakan bahwa kartun pembelajaran matematika menarik digunakan sebagai media dalam pembelajaran. Kemudian pada uji coba lapangan, ada kenaikan rata-rata nilai hasil belajar dari pretest yaitu pada saat posttest dari segi tingkat ketuntasan klasikal, diperoleh hasil pretest sebanyak 6,45 \% tuntas dan hasil posttest sebanyak $80,54 \%$ tuntas.

\section{UCAPAN TERIMA KASIH}

Terimakaish kepada seluruh responden yang telah bersedia, sehingga penelitian ini dapat saya selesaikan. Serta semua elemen yang telah ikut berpartisipasi, saya ucapkan terimakasih

\section{REFERENSI}

[1] A. Asrial, S. Syahrial, D. A. Kurniawan, R. Septiasari, "Hubungan Kompetensi Pedagogik Dengan Kompetensi IPA Mahasiswa Pendidikan Guru Sekolah Dasar," Pedagogia: Jurnal Penididikan, vol. 8, no. 2, pp. 149-157, 2019

[2] S. Syahrial, A. Asrial, D. A. Kurniawan, P. Nugroho, R. Septiasari, R. A. Pratama, and R. Perdana, "Increased Behavior of Students' Attitudes to Cultural Values Using the Inquiry Learning Model Assisted Ethno constructivism," Journal of Educational Science and Technology (EST), vol. 5, no. 2, pp. 166-175, 2019

[3] A. Azhar. "Media Pembelajaran". Jakarta: PT. Rajagrafindo Persada. 2009

[4] A. Asrial, S. Syahrial, D. A. Kurniawan, M. Subandiyo, and N. Amalina, "Exploring Obstacles in Leanguage Learning Among Prospective Primay School Teacher," International Journal of Evaluation and Research in Education, vol. 8, no. 2, pp. 249-254, 2019

[5] Asyhar, Rayandra. Kreatif Mengembangkan Media Pembelajaran. Jakarta: Gaung Persada 2011

[6] D. A. Kurniawan, A. Astalini, D. Darmaji, R. Melsayanti, "Student's Attitude Towards Natural Science," International Journal of Evaluation and Research in Education (IJERE), vol. 8, no. 3, pp. 463-468, 2019

[7] Darmaji, D. A Kurniawan, Astalini, A. Lumbantoruan, and S. C. Samosir. "Mobile Learning In Higher Education For The Industrial Evolutioin 4.0: Perception and Response of Physics Practicum," International Journal of Interactive Mobile (IJIM), vol. 13, no. 9, pp. 4-20, 2019

[8] A. Asrial, S. Syahrial, D. A. Kurniawan, and N. Amalina, "Analisis Hubungan Kompetensi Bahasa Indonesia Terhadap Kompetensi Pedagogik Mahasiswa Pendidikan Guru Sekolah Dasar," Premiere Educandum: Jurnal Pendidikan Dasar dan Pembelajaran, vol. 9, no. 1, pp. 1-8, 2019.

[9] D. Darmaji, D. A. Kurniawan, A. Astalini, and N. R. Nasih, "Persepsi Mahasiswa pada Penuntun Praktikum Fisika Dasar II Berbasis Mobile Learning," Jurnal Pendidikan: Teori, Penelitian, dan Pengembangan, vol. 4, no. 4, pp. 516-523, 2019.

[10] Utomo, Prasetyo Eko. Pengembangan Lembar Kerja Siswa dengan Media Ilustrasi Komik (Upaya Meningkatkan Hasil Belajar Siswa pada Mata Pelajaran IPS-Ekonomi di Kelas VII SMP Negeri 2 Gondang Bojonegoro. Online:2012

[11] D. Darmaji, A. Astalini, D. A. Kurniawan, and R. Perdana, "A study relationship attitude toward physics, motivation, and character discipline students senior high school, in Indonesia," International Journal of Learning and Teaching, vol. 11, no. 3, pp. 99-109, 2019.

[12] M. Maison, D. Darmaji, A. Astalini, D. A. Kurniawan, and P. Indrawati, "Science process skills and motivation," Humanities \& Social Sciences Reviews (HSSR), vol. 7, no. 5, pp. 48-56, 2019

[13] Sadiman, S. Arief. "Media Pendidikan”. Jakarta: PT RajaGrafindo Persada., 2012

[14] SPunaji. "Metode Penelitian Pendidikan dan Pengembangan". Jakarta: Prenadamedia Group, 2010 